\title{
ニフェジピン歯肉増殖症におけるランゲルハンス細胞の 上皮内分布および密度に関する免疫組織化学的研究
}

\author{
尾崎幸生國松和司田尻公一 \\ 原宜興加藤伊八 \\ 長崎大学歯学部歯科保存学第二講座 \\ (主任：加藤伊八教授) \\ (平成 10 年 2 月 9 日受付)
}

\author{
Immunohistochemical Study on Intraepithelial Distribution and Density of \\ Langerhans Cells in Nifedipine-induced Overgrown Gingival Tissues \\ Yukio Ozaki, Kazushi Kunimatsu, Koichi Tajiri, \\ Yoshitaka Hara and Ihachi Kato \\ Department of Periodontology, Nagasaki University School of Dentistry \\ 1-7-1 Sakamoto, Nagasaki 852-8588, Japan \\ (Cheif : Prof. Ihachi Kato)
}

In order to clarify the roles of Langerhans cells (LCs) associated with host defence mechanisms in nifedipine (NF)-induced gingival overgrowth, the intraepithelial distribution and density of LCs in tissues from the following four groups were examined. Using a rabbit anti-human S-100 protein antibody assay, gingival tissue samples from patients with NF-induced gingival overgrowth (NF-responders, R group) were compared with those from NF-nonresponders (NR group), proliferative gingivitis patients secondary to the presence of dental plaque (ND group) and systemically healthy subjects (Ctrl group). Five patients in each group were randomly selected and all gave informed consent to take part in this study. Gingival tissue samples were carefully taken during periodontal flap surgery or tooth extraction and the serial specimens were embedded in paraffin and routinely processed. The specimens were immunostained with anti-S-100 protein polyclonal antibody followed by histological analysis of the positive cells in gingival epithelium. The S-100 positive LCs were defined as the total S-100 positive cells minus those positive cells identified with
Schmorl stain. Histologically, the S-100 positive cells from the specimens in all groups were scattered in both the basal and the spinous layers. The percentages of positive cells per total epithelial cells in all groups were increased in the following order, $\mathrm{R}>\mathrm{ND}>\mathrm{NR}>$ Ctrl. Statistically significant differences were seen between the groups, $\mathrm{R}$ and $\mathrm{ND}$ $(\mathrm{p}<0.05), \mathrm{R}$ and NR $(\mathrm{p}<0.01), \mathrm{ND}$ and NR $(\mathrm{p}<$ 0.05), R and Ctrl $(\mathrm{p}<0.01)$, and ND and Ctrl $(\mathrm{p}<$ $0.05)$. On the contrary, no significance was seen between the groups of NR and Ctrl. The gingival epithelium investigated in this study was divided into two groups, S-100 protein positive LC-rich area and S-100 protein positive LC-poor area in each group. CD 3- positive cells appeared to be greatly infiltrated in the connective tissue beneath the epithelium accumulated by LCs. This tendency was remarkable especially in the $\mathrm{R}$ group. Similarly, the connective tissues examined were divided into two regions, the densely and/or sparsely infiltrated region by inflammatory cells. In comparison with the frequency of S-100 positive LCs in the connective tissues beneath each region, a significant relationship was seen only in the ND group $(p<0.05)$.

本論文の要旨は, Japanese Association for Dental Research 44 th Annual Meeting 1996（1996 年 11 月 26 日）におい て発表した。 
Also, the frequency of LCs in the epithelium of the $\mathrm{R}$ group among the sparsely infiltrated regions was significantly higher than any other groups $(p<$ $0.01)$. Considering that the S-100 positive LCs were significantly increased in the oral epithelium and that a large number of CD 3-positive cells was infiltrated beneath the epithelium, our findings suggest the enhancement of the pathophysiological roles of LCs and CD 3-positive cells in NF-induced gingival overgrowth.

Key words : Langerhans cell, S-100 protein, Nifedipine-induced gingival overgrowth, CD 3-positive cell 要旨：宿主免疫機構に関与するランゲルハンス細胞 (LC) のニフェジピン (NF) 歯肉増殖症における役割を 調べる目的で, NF 誘発性歯肉増殖症患者 (NF-responders, $\mathrm{R}$ 群), NF 非感受性歯周炎患者 ( $\mathrm{NR}$ 群), プ ラークに起因する増殖性歯肉炎患者（ND群）および全身疾患を持たない臨床的健康歯肉保有患者（Ctrl 群）か ら得られた歯肉組織中に存在する LC の上皮内分布ならびに存在密度を抗 S-100 蛋白抗体を用いて検索し, 比 較検討した。各群からそれぞれ 5 名ずつ被検者を任意に選択し，患者から同意を得た上で歯周外科時あるいは抜 歯時に試料を採取してパラフィン包埋連続切片を作製した。これらの切片にウサギ抗 S-100 蛋白ポリクローナ ル抗体を用いて免疫染色を施し, 歯肉上皮内に扔ける S-100 蛋白陽性細胞の組織学的検索を行った。なお，計 測時に全 S-100 蛋白陽性細胞数から連続切片に抢けるシュモール染色陽性細胞数を差し引いたものを S-100 蛋 白陽性 LC 数とした。その結果, S-100 蛋白陽性細胞は, 各群の歯肉上皮の基底層から有棘層にかけて散在性に 存在していた。なかでも，歯肉上皮の単位面積あたりに存在する総上皮細胞に対する LC の百分率は R 群 > ND 群 $>\mathrm{NR}$ 群 $>\mathrm{Ctrl}$ 群の順に高く， R 群と ND 群， R 群と NR 群， ND群と NR 群， R 群と Ctrl 群，および ND 群と Ctrl 群との間にそれぞれ $\mathrm{p}<0.05, \mathrm{p}<0.01, \mathrm{p}<0.05, \mathrm{p}<0.01$ および $\mathrm{p}<0.05$ で有意差を認めた。なお， $\mathrm{NR}$ 群と Ctrl 群との間には有意差は認められなかった。また，歯肉上皮を LC に富んだ領域と少ない領域に分 けた場合, LC が多く集積する上皮直下の結合組織中に CD 3 陽性細胞が多数浸潤する傾向がみられた。この傾 向は, 特に R 群において顕著であった。さらに, 結合組織を炎症性細胞浸潤密度の高い領域と低い領域に分け, その直上の上皮内における LC の出現頻度を比較すると, ND 群でのみ有意な差がみられた $(\mathrm{p}<0.05)$ 。また, 炎症性細胞浸潤密度の低い領域における R 群の LC の比率は, 他群に比べて有意に高い值を示した $(\mathrm{p}<0.01)$ 。 以上より, NF 歯肉増殖症では口腔上皮内に LC が有意に増加し，またその上皮直下結合組織に多くの CD 3 陽 性細胞が浸潤していることから，本疾患においてこれらの細胞の果たす役割が増強されている可能性が示唆され た。しかし，炎症性細胞浸潤の程度と LC の分布との関連を明らかにすることはできなかった。

索引用語: ランゲルハンス細胞, S-100 蛋白, ニフェジピン誘発性歯肉增殖症, CD 3 陽性細胞

\section{緒言}

カルシッム拈抗唷ニフェジピン (以下 NF と略 す) $)^{1)}$ ，免疫抑制剤のサイクロスポリン $\mathrm{A}^{2)}$ や抗てん かん薬フェニトインふなどとともに, 薬剤の副作用と して歯肉の増殖性疾患を引き起こすことが知られてい る。近年, $\mathrm{NF}$ 誘発性歯肉増殖症は, 口腔清掃, 咀嚼 や発音を困難にするだけでなく，審美的な障害をも招 くため病因の解明が切望されている。しかしながら, 本疾患による宿主組織抢よび細胞の生理的・病理的変 化ならびに動態等に関してはまだ充分には解明されて 抢らず，特に，炎症反応や免疫機構との関連について は，その重要性にもかかわらず不明の点が多い4 8)。

抗原提示機能に直接関与する MHCクラス II 細 胞膜上に保有し，上皮に侵入したさまざまな刺激因子 をT細胞に呈示するラングルハンス細胞（以下 LC と

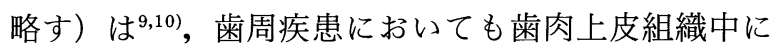

多く存在し ${ }^{11 ~ 13)}$, 生体防御の最前線としての役割を 担っている。一般に，いずれの薬剂性歯肉増殖症にお いても, 上皮組織の肥厚や角化の充進あるいは上皮脚 の不規則ふ伸長を認め, 口腔上皮の防御能が增強して いることが推察される ${ }^{4,5,14)}$ 。過去に, 宿主防御機構の 一役を担う LC と薬剤誘発性歯肉増殖症の関連に着目 した研究も数例報告されているが ${ }^{15 \sim 18)}, \mathrm{NF}$ 誘発性七 卜歯肉増殖症における報告は皆無である。そこで今 回, $\mathrm{NF}$ 歯肉増殖症歯肉上皮に扔ける LC の動態を, その代表的なマーカーの一つである抗 S-100 蛋白抗 体 ${ }^{10,19)}$ を用いて検索し, 併せて, LC が抗原を提示す るTリンパ球の組織内分布についても検討を加え, $\mathrm{NF}$ 歯肉增殖症に扔ける宿主防御機構の特異性につい て若干の知見を得たので報告する。 


\section{材料および方法}

\section{1. 被検者}

被検者は, 長崎大学歯学部附属病院第二保存科を受 診した患者の中から NFを 3 力月以上服用し, 臨床 的に歯肉増殖を来した患者 (Responder, 以下 $\mathrm{R}$ 群, 平均年齢 66.3 歳, 男 2 名, 女 3 名), その対照として 同薬剤を同様な期間および 1 日量服用しているが歯肉 増殖を認めない患者 (Non-responder, 以下 NR 群, 平均年齢 62.4 歳, 男 4 名, 女 1 名), 歯肉の増殖を来 す可能性のある薬剤を全く服用していないプラークに 起因する増殖性歯肉炎患者 (Non-drug, 以下 ND 群, 平均年齢 40.2 歳, 男 2 名, 女 3 名), および臨床 的健康歯肉を有するう蝕症などの患者 (Control, 以 下 Ctrl 群, 平均年齢 43.0 歳, 男 1 名, 女 4 名）の 4 つの群に分け, 臨床パラメーターに基づき各群から任 意に 5 名の被検者を選択した（表 1 ）。なお, NFを 服用しているが口腔内に歯肉増殖が見られず，採取部 位にのみ歯周ポケットが存在する場合に，これを成人 性歯周炎によるNon-responder 歯肉と定義した。

\section{2. 試料の採取および切片の作製}

患者より同意を得た上で，抜歯および歯周外科手術 の際に歯肉片（R，NR，ND，Ctrl群それぞれ 14, 14，12，7 部位）を注意深く採取した（表 1)。また採 取直前に, 同部位の臨床評価として, 臨床パラメー ターである Probing Depth (PD) および Gingival Index $(\mathrm{GI})^{20)}$ を同一検者がこの順に計測した。PD の測定は, Williams 歯周プローブ (Hu-Friedy Co., Chicago, IL) を用い, mm 単位で記録した。

採取した試料は, PLP (periodate-lysine- paraformaldehyde) にて固定後，パラフィン包埋し， $4 \mu \mathrm{m}$ 厚の連続切片を $1 つ の$ 試料に対し 4 枚作製し た。その内訳は, 順に, ヘマトキシリンーエオジン染 色 (以下 H.E. と略す) 用, メラニン細胞同定のため のシュモール染色用, S-100 蛋白陽性細胞検出のため のウサギ抗 S-100蛋白ポリクローナル抗体 (LSL CO., LTD., USA) 用, そしてTリンパ球検出マー カーの CD 3 モノクローナル抗体 (ZYMED LABO., INC., USA）用である。ここで, シュモール染色 ${ }^{21}$ は 上皮組織に存在するメラニン細胞が LC と同様に S100 蛋白を保有する ${ }^{10,19)}$ こから，両者を識別するた めに用いられた染色法である。

\section{3. 免疫染色}

免疫染色の手順は ABC法（avidin-biotinperoxidase complex method）を一部改変7して行っ た。まず，薄切パラフィン切片を脱パラフィンした 後, $0.5 \mathrm{MNaCl}$ 添加 PBS (phosphate-buffered saline, pH 7.4）にて洗浄した。10\%正常ヤギ血清と 室温で 30 分間反応させ, 非特異的な蛋白の結合をブ ロックした後，一次抗体を負荷し， $4^{\circ} \mathrm{C}$ に一晚反応 させた。これ以後の操作はすべて室温にて行った。二 次抗体として抗ウサギ免疫グロブリンと 10 分間反応 させ， $3 \%$ 過酸化水素含有メタノールにて 15 分間内 因性ペルオキシダーゼを不活性化させ, ABC と 5 分 間反応させた。最後に, Karnovskyの溶液 (3,3' -diaminobenzidine tetrahydrochloride in $100 \mathrm{~m} l$ of $0.05 \mathrm{M}$ Tris buffer, pH 7.4, containing $0.3 \%$ hydrogen peroxide and distilled water) 中で反応産物を 5 〜 10 分間発色させた。なお，抗体の希釈と切片の洗 净には $0.5 \%$ ミルクプロテインおよび $0.05 \%$ Triton X-100 含有 PBS 溶液を用い, 各ステップ間で充分な

表 1 被検者と被検部位数ならびに臨床デー夕

\begin{tabular}{|c|c|c|c|c|}
\hline & \multicolumn{2}{|c|}{ Nifedipine taking patients } & \multirow{2}{*}{$\begin{array}{l}\text { Non-drug taking } \\
\text { patients } \\
\text { (ND) }\end{array}$} & \multirow{2}{*}{$\begin{array}{l}\text { Control } \\
\text { (Ctrl) }\end{array}$} \\
\hline & $\begin{array}{l}\text { Responder } \\
\text { (R) }\end{array}$ & $\begin{array}{c}\text { Non-responder } \\
\text { (NR) }\end{array}$ & & \\
\hline Subject & $5<\begin{array}{l}2 \text { males } \\
3 \text { females }\end{array}$ & $\begin{array}{l}5<4 \text { males } \\
1 \text { female }\end{array}$ & $\begin{array}{l}5<2 \text { males } \\
3 \text { females }\end{array}$ & $5<\begin{array}{l}1 \text { male } \\
4 \text { females }\end{array}$ \\
\hline Samples & 14 & 14 & 12 & 7 \\
\hline $\begin{array}{l}\text { Mean } \\
\text { Age }\end{array}$ & $\begin{array}{l}66.3 \mathrm{Ys} \\
(60-78)\end{array}$ & $\begin{array}{l}62.4 \mathrm{Ys} \\
(60-68)\end{array}$ & $\begin{array}{l}40.2 \mathrm{Ys} \\
(19-65)\end{array}$ & $\begin{array}{l}43.0 \mathrm{Ys} \\
(30-56)\end{array}$ \\
\hline $\begin{array}{l}\text { Mean PD } \\
\quad \pm \text { SD }\end{array}$ & $5.4 \pm 0.5$ & $5.0 \pm 1.3$ & $4.8 \pm 1.0$ & $1.7 \pm 0.5$ \\
\hline \multirow[t]{2}{*}{$\begin{array}{c}\text { Mean GI } \\
\pm \text { SD }\end{array}$} & $2.1 \pm 0.4$ & $1.8 \pm 0.7$ & $2.3 \pm 0.5$ & $0.7 \pm 0.5$ \\
\hline & & & $\begin{array}{l}\text { PD ; Probing } \\
\text { GI ; Gingival }\end{array}$ & $\begin{array}{l}\text { h (mm) } \\
\text { x (Löe, 1967) }\end{array}$ \\
\hline
\end{tabular}




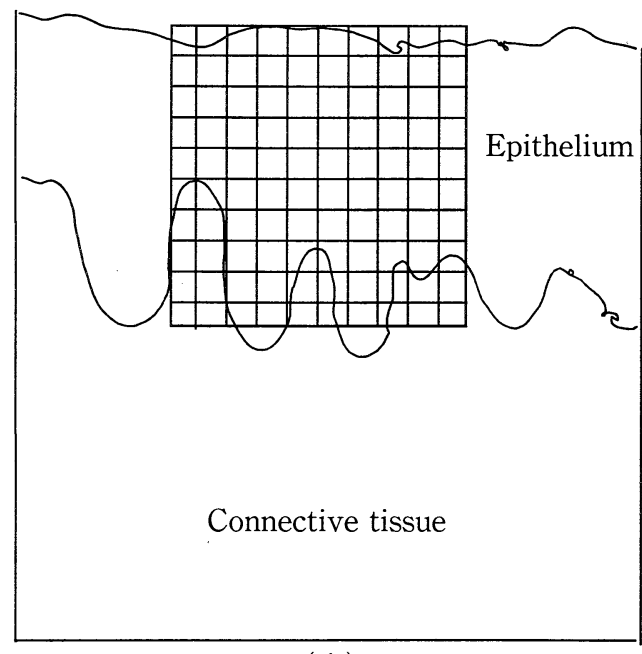

(A)

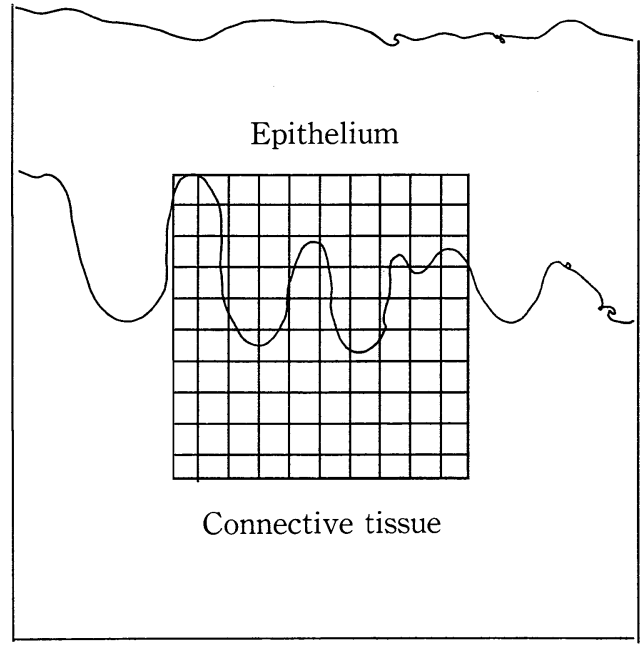

(B)

図 1 S-100 蛋白陽性細胞の組織学的計測方法

(A) 検鏡下にて歯肉上皮内に計測のための一 定領域（グリッドで示した部分，面積 0.125 $\mathrm{mm}^{2}$ ) を選定し，その領域に存在する上皮細 胞の総数に対する LC 数の比率を算定した。

(B) 口腔上皮を LCが多く存在する部位 (LC-rich 部) と少ない部位（LC-poor 部）に 分け，その各々の領域における上皮直下結合組 織（グリッドで示した部分，面積 0.125 $\mathrm{mm}^{2}$ ) 中に存在する $\mathrm{CD} 3$ 陽性 $\mathrm{T}$ 細胞数を計測 した。

洗浄を行った。また，一次抗体として用いたウサギ抗 S-100蛋白ポリクローナル抗体は500倍希釈，抗 CD 3 モノクローナル抗体は 10 倍希釈して使用し, 対 比核染色はへマトキシリンにて行った。正常ヤギ血
清, 二次抗体, $\mathrm{ABC}$ はヒストファイン®(ニチレイ社 製，東京）を使用した。

\section{4. 計測方法}

図 1 (A) に示すように, 検鏡下にて歯肉上皮内に任 意に 10 ケ所の計測のための一定領域（グリッドで示 した部分, 面積 $0.125 \mathrm{~mm}^{2}$ ) を選定し，その領域に 存在する上皮細胞の総数に対する LC 数の比率を算定 した。なお，計測時に全 S-100 蛋白陽性細胞数から 連続切片におけるシュモール染色陽性細胞数を差し引 いたものを LC 数とした。また, LC と T 細胞との関 連を検索するため，口腔上皮を LC が多く存在する部 位と少ない部位，すなわち単位面積において $2 \%$ 以上 の LC 率を示した部位を LC-rich 部, 同じく $2 \%$ 未満 の部位を LC-poor 部とし, その直下結合組織（図 1 (B)においてグリッドで示した部分, 面積 0.125 $\mathrm{mm}^{2}$ ) に存在する CD 3 陽性 $\mathrm{T}$ 細胞数を計測した。

さらに，LC と炎症性細胞の関連を検索するため, 上皮直下の結合組織 $0.125 \mathrm{~mm}^{2}$ の領域を炎症性細胞 浸潤が多い部位と少ない部位, すなわち炎症性細胞が 150 個末満の Mild Infiltration部と 150 個以上の Severe Infiltration部に分けて，それぞれに接する LC 率を算出した。

\section{5. 統計学的分析}

被検者の NF 服用期間, 1 日服用量, $\mathrm{PD}$ 值, GI 值, 歯肉上皮の単位面積あたりの LC 率, LC-rich 部 および LC-poor 部における CD 3 陽性細胞数，ならび に Mild infiltration 部および Severe infiltration 部に おけるLC率の分析に際して，各群間の比較には Mann-Whitney's U-testを, 群内での比較にはWilcoxon signed-ranks testを用いて統計学的検索を 行った。

\section{結＼cjkstart果}

\section{1. 被検部位の臨床評価}

今回検索した R 群，NR 群，ND群ならびに Ctrl 群の被検部位の平均 $\mathrm{PD}$ 值はそれぞれ $5.4 \pm 0.5$ $\mathrm{mm}, 5.0 \pm 1.3 \mathrm{~mm}, 4.8 \pm 1.0 \mathrm{~mm}$ および $1.7 \pm 0.5$ $\mathrm{mm}$ であり，平均 $\mathrm{GI}$ 值はそれぞれ $2.1 \pm 0.4 ， 1.8 \pm$ $0.7 ， 2.3 \pm 0.5$ および $0.7 \pm 0.5$ で Ctrl 群を除いた各 群間に統計学的な有意差は認められなかった（表 1)。 また， R 群および NR 群の NF 服用期間はそれぞれ 平均 $18.8 \pm 7.8,16.1 \pm 13.0$ 力月,さらに，1 日服用 量は $42.0 \pm 16.4,34.0 \pm 10.7 \mathrm{mg}$ で, 両者共に有意 差はなかった。 


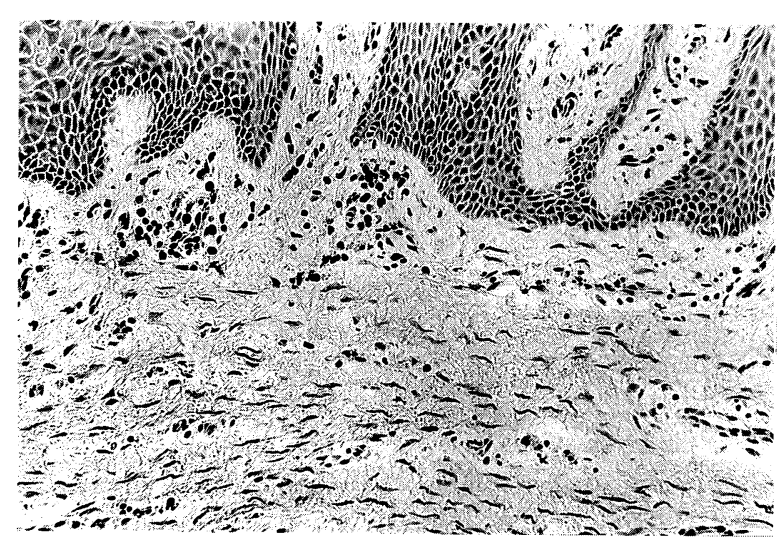

図 2 Control (Ctrl 群) の H.E. 染色像 (X 50)

炎症性細胞浸潤は軽度で, 結合組織深部のコ ラーゲン線維の走行は規則正しい。

\section{2. 組織学的所見}

1) H.E. 染色所見

$\mathrm{Ctrl}$ 群の歯肉では上皮の肥厚, 上皮脚の伸長およ び炎症性細胞の浸潤は殆どみられず，結合組織深部に おけるコラーゲン線維の走行も規則正しかった（図 2)。一方, $R$ 群歯肉の口腔上皮では, 有棘層の肥厚, 不規則に伸長した上皮脚ならびに錯角化がみられ, 結 合組織では深部においてコラーゲン線維が密に太い束 を形成し, 錯走しているものが多く認められた（図 3)。また, 炎症性細胞浸潤は主としてポケット上皮直 下と口腔上皮直下に多くみられたが, 結合組織深部に おいて形質細胞を主体とする集塊を形成している症例 も認められた。さらに, NR 群歯肉に扔いては Ctrl 群に比べて上皮の肥厚やポケット上皮直下と口腔上皮 直下に炎症性細胞浸潤が見られたが， $\mathrm{R}$ 群に比べて顕 著ではなかった。ND群では上皮の肥厚と不規則な伸 長が認められ, 結合組織でも密に錯走するコラーゲン 線維の束が認められたが, いずれも $\mathrm{R}$ 群の歯肉と比 較すると顕著ではなかった。しかし, 炎症性細胞浸潤 の程度は他の群に比べて著しく強かった。

2）歯肉上皮内における S-100 蛋白陽性細胞の組 織学的所見

S-100 蛋白陽性細胞は, 各群とも歯肉上皮の基底層 から有棘層にかけて散在していた。しかし, 同一切片 内においても出現頻度や出現部位に多少の相違が認め られた。陽性細胞は Ctrl 群の歯肉では極めて少数で あったのに対し，R群では多数認められた（図 4)。 さらに, NR 群では Ctrl 群と同様に陽性細胞数は極 めて少なかったのに対し (図 5), ND群では数多く 認められたが，その数は $\mathrm{R}$ 群と比べると少なかった

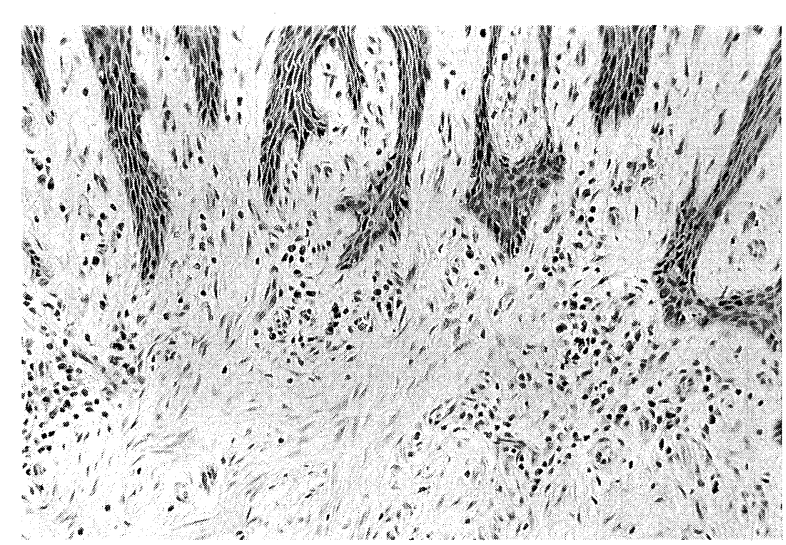

図 $3 \mathrm{NF}$ 感受性増殖歯肉 (R 群) の H.E. 染 色像 $(\times 50)$

結合組織深部のコラーゲン線維は密に太い束 を形成し，錯走している。

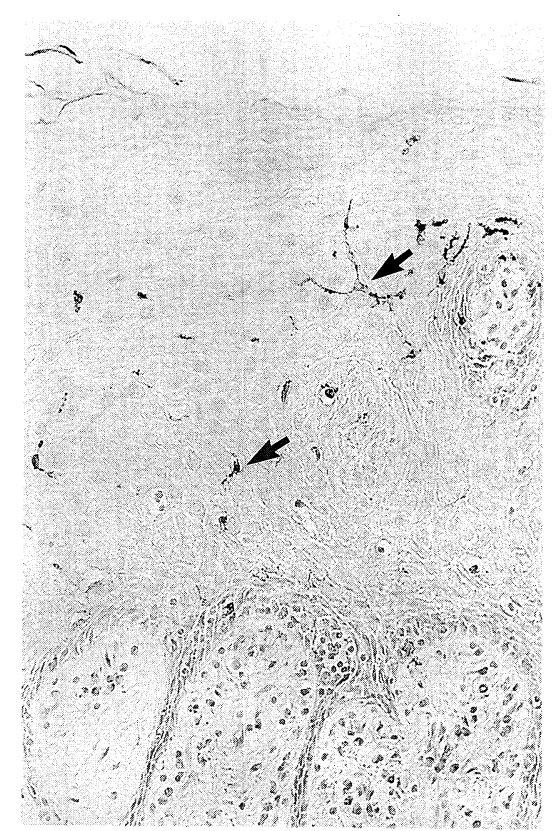

図 $4 \mathrm{NF}$ 感受性増殖歯肉 ( $\mathrm{R}$ 群) の抗 S-100 蛋向杭体による免 疫染色像 $(\times 66)$

S-100 蛋白陽性細胞が基底層から 有棘層にかけて散在性に数多く認め られる (矢印)。

(図 6)。

以上の結果をまとめると， S-100 蛋白陽性細胞は R 群 $>\mathrm{ND}$ 群 $>\mathrm{NR}$ 群 $>\mathrm{Ctrl}$ 群の順に多く認められた。

3） CD 3 陽性細胞の組織学的所見

CD 3 陽性細胞は, 各群とも S-100 蛋白陽性細胞が 


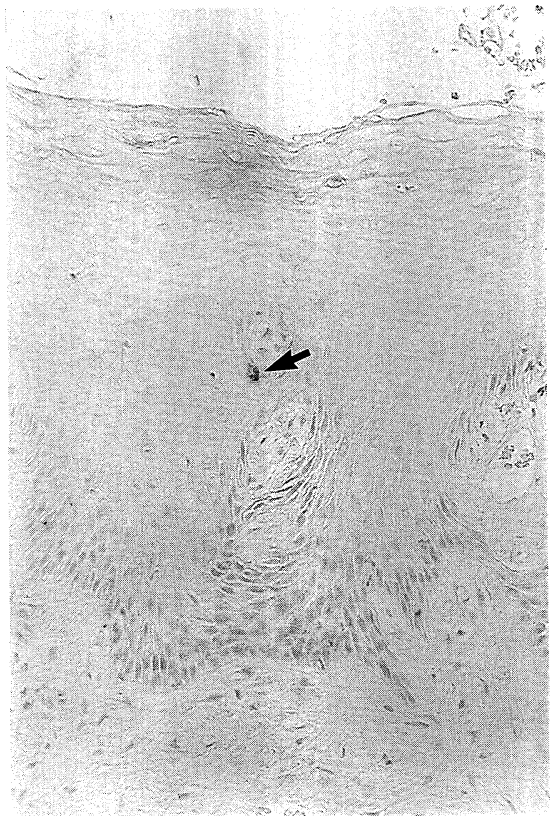

図 $5 \mathrm{NF}$ 非感受性歯肉 (NR 群) の 抗 S-100 蛋白抗体による免疫染 色像 $(\times 66)$

S-100 蛋白陽性細胞が基底層から有 棘層にかけて散在性に認められる（矢 印)。R 群および ND群に比べるとそ の数は軽微である。

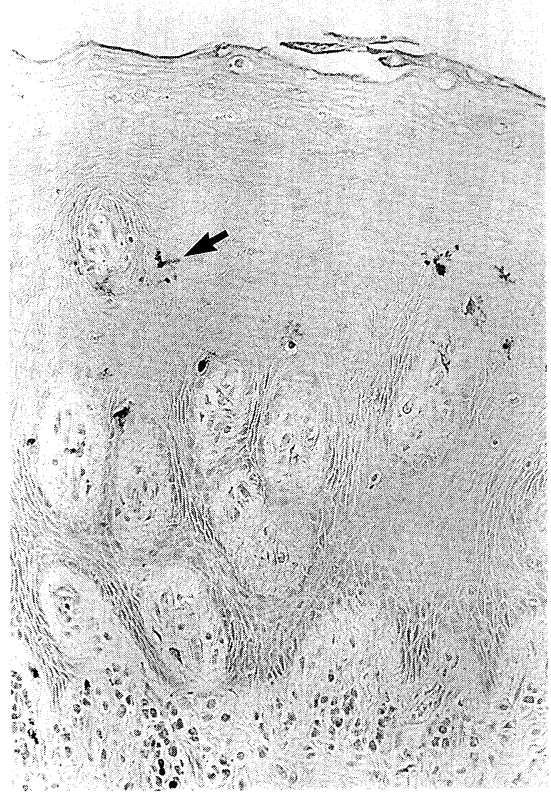

図 6 プラークに起因する増殖性歯肉 炎患者 (ND 群) の抗 S-100 蛋白 抗体による免疫染色像 $(\times 66)$

S-100 蛋白陽性細胞が基底層から有 棘層にかけて散在性に認められる（矢 印)。その数は R 群よりは少なく, NR群よりは多い。
多く検出された部位に一致して多数集積していた（図 $7 \mathrm{~A}, \mathrm{~B})$ 。

\section{3. 総歯肉上皮細胞に対する LC の存在比率}

歯肉上皮の単位面積 $\left(0.125 \mathrm{~mm}^{2}\right)$ あたりの S-100 蛋白陽性細胞の平均值は $\mathrm{R}$ 群 $16.5 \pm 5.2$ 個, $\mathrm{NR}$ 群 6.1 \pm 3.5 個，ND 群 $10.3 \pm 2.4$ 個，Ctrl 群 $2.5 \pm 0.7$ 個で，シュモール染色陽性細胞はそれぞれ $2.5 \pm 1.0$

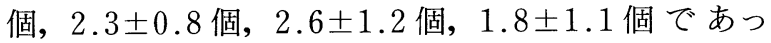
た。この結果，総歯肉上皮細胞に対する LC の出現頻 度 は R 群 $3.6 \pm 1.7 \% ， \mathrm{NR}$ 群 $1.3 \pm 1.1 \%$, ND 群 $2.3 \pm 0.8 \%$, Ctrl 群 $0.7 \pm 0.7 \%$ であり, R 群と NR 群 $(\mathrm{p}<0.01), \mathrm{ND}$ 群 $(\mathrm{p}<0.05)$ お よ゙ Ctrl 群 $(\mathrm{p}<0.01)$ との間で, ND群と NR 群 $(\mathrm{p}<0.05)$, Ctrl 群 $(\mathrm{p}<0.05)$ との間で有意差が認められた。こ れに対し, NR群とCtrl 群との間には有意差は認め られなかった(図 8)。

\section{4. 歯肉上皮直下結合組織中における Tリンパ球 （CD 3 陽性細胞）の分布}

R 群の LC-rich および LC-poor 領域における平均 CD 3 陽性細胞数はそれぞれ $42.9 \pm 13.0$ 個, $20.8 \pm$ 6.1 個であり, ND群では $30.9 \pm 6.8$ 個, $14.6 \pm 3.8$
個であった。各群で rich， poor 領域間（p<0.01）に おいて，また両群の LC-rich 領域間（p<0.05）で有 意差が認められた。さらに, NR 群, Ctrl 群の LCpoor 領域での平均陽性細胞数は $8.0 \pm 3.4$ 個, $7.3 \pm$ 5.8 個であり，LC-poor 領域において R 群と NR 群 $(\mathrm{p}<0.01), N D$ 群 $(\mathrm{p}<0.05)$ ，押よび Ctrl 群 $(\mathrm{p}<$ $0.01)$ 間で，また ND群と Ctrl 群 $(\mathrm{p}<0.05)$ 間 C 有意差が認められた（図9）。なお，NR群抢よび Ctrl 群において LC-rich 領域は極めて稀であり，標 本数が少数であったため統計処理から除外した。

\section{LC と炎症性細胞浸潤との関連}

$\mathrm{R} ， \mathrm{NR}$ および ND 群の Severe infiltration 部にお けるLCの比率は，それぞれ $3.9 \pm 2.0 \%, 1.4 \pm$ $1.4 \%$ および $3.0 \pm 1.4 \%$ であった。これに対し， R,

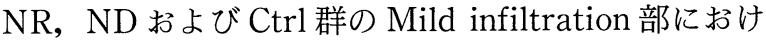
る LCの比率は， $3.4 \pm 1.5 \%, 1.1 \pm 0.9 \%, 1.7 \pm$ $0.6 \%$ および $0.7 \pm 0.7 \%$ であり, ND群のみに Severe および Mild infiltration 部間で有意差を認め た $(\mathrm{p}<0.05)$ 。また, Severe infiltration 部において

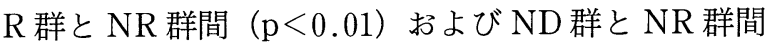
$(\mathrm{p}<0.05)$ で有意差が認められた。一方，Mild infil- 

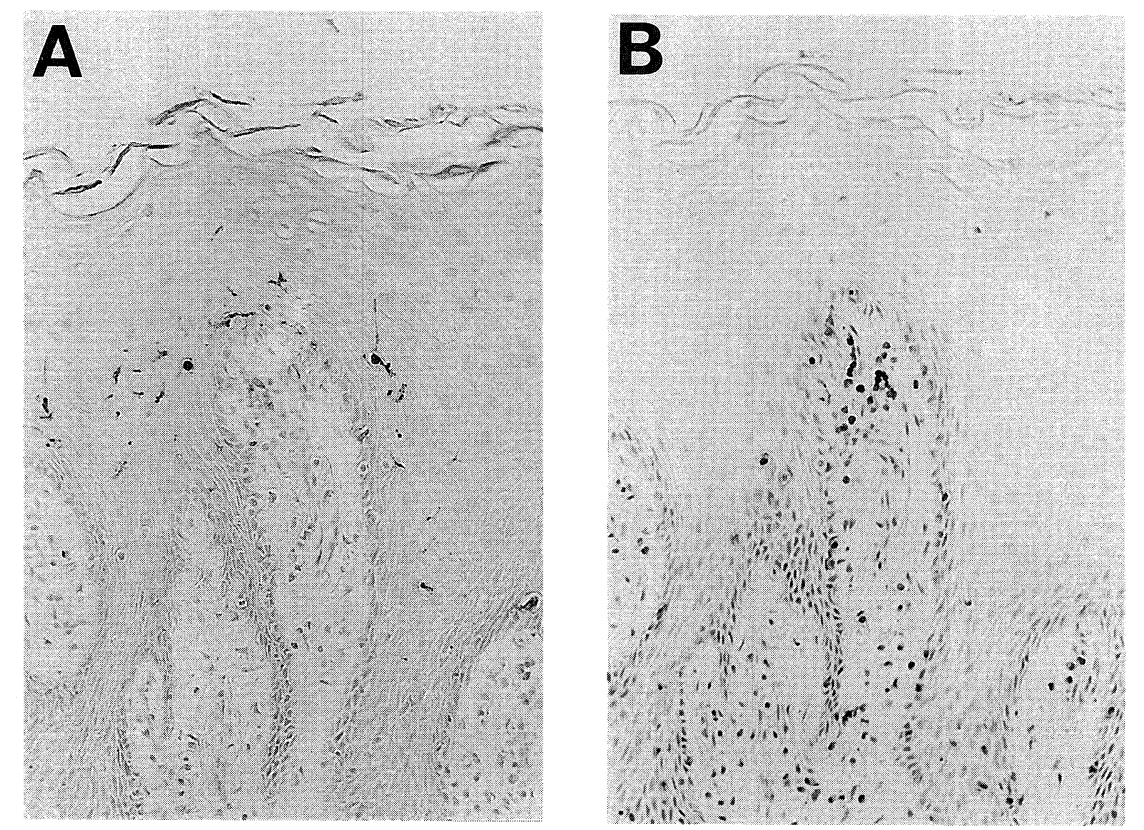

図 7 (A) R 群歯肉上皮内の S-100 蛋白陽性細胞の染色像 $(\times 66)$

(B) 同部位に扔ける CD 3 陽性細胞の染色像 $(\times 66)$

S-100 蛋白陽性細胞が数多く存在する上皮組織に近接した結合組織中

に, CD 3 陽性細胞が浸潤する傾向が認められる。

tration 部において R 群と NR 群（p<0.01），ND群 $(\mathrm{p}<0.01)$ および $\mathrm{Ctrl}$ 群間（p<0.01）において，ま た ND群と Ctrl 群間（p<0.05）において有意差を 認めた（図 10）。

\section{考察}

上皮組織中に存在し，生体防御の最前線としての役 割を担うランゲルハンス細胞 (LC) は，口腔内にお

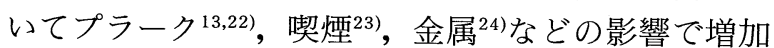

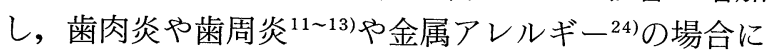
口腔上皮に多く出現することが報告されている。薬剤 性の歯肉增殖症においても，フェニトイン誘導性では 增加するが16 18)，师少口スポリン誘導性では逆に 減少する ${ }^{15)}$ 。これに対し, NF 誘導性歯肉増殖症にお ける LC の出現頻度に関する報告はこれまで皆無であ るため, 今回我々は, $\mathrm{NF}$ 感受性歯肉 ( $\mathrm{R}$ 群) を対象 として LC の出現に関する検索を行った。その結果, 全ての症例において LC が検出され, NF 非感受性歯 肉（NR 群）やプラークが原因とされる歯肉炎 (ND 群）の歯肉上皮よりも $\mathrm{S}-100$ 蛋白陽性 LC 率が有意 に増加していた。この所見は，我々が過去に報告した フェニトイン誘導性と同様に, 本疾患に扔いても LC の果たす役割が増強されている可能性を示唆するもの
である。この LC の増加の原因として，マクロファー ジや上皮細胞が NFにより刺激され，インターロイ キン-1 などのサイトカインの産生が立進し ${ }^{25)}$, その 結果 LC が歯周組織内に多数誘導された可能性が考え られる5,17)。また，一般に LC は上皮の角化過程の調 節に関与していると考元られ ${ }^{26,27)}$, 歯肉増殖症におい てこのような機能が六進したため ${ }^{28} \mathrm{LC}$ の数が増加し たのかもしれない。しかし，この方面の研究は少な く, 詳細は不明のため今後に残された課題とも言え る。

$\mathrm{NF}$ 療法におけるNon-responderの発現率は約 $80 \%{ }^{5)}$ と高率でありながら, この群の詳細な特徴はま だ明らかにされてはいない。Barakら ${ }^{144} は$ ，Responder ひみならず Non-responder においても上皮の肥 厚を認めているが, 今回我々の NR 群に扔いても多 くの症例でコントロールに比べ上皮の肥厚が見られ た。また, 炎症性細胞浸潤, さらに有意差はないが LC の存在密度の上昇傾向を認めた。これは， $\mathrm{R}$ 群と の比較のために臨床パラメーターである PD と GI 值 を両群で同等となるように考慮したため, 比較的炎症 が強い症例を優先的に採用したことが原因と考えられ る。本研究では，NR 群において LC が顕著に少ない という興味ある所見が得られたが，今後 NR 群にお ける炎症性細胞浸潤の程度差にも着目した LC の出現 


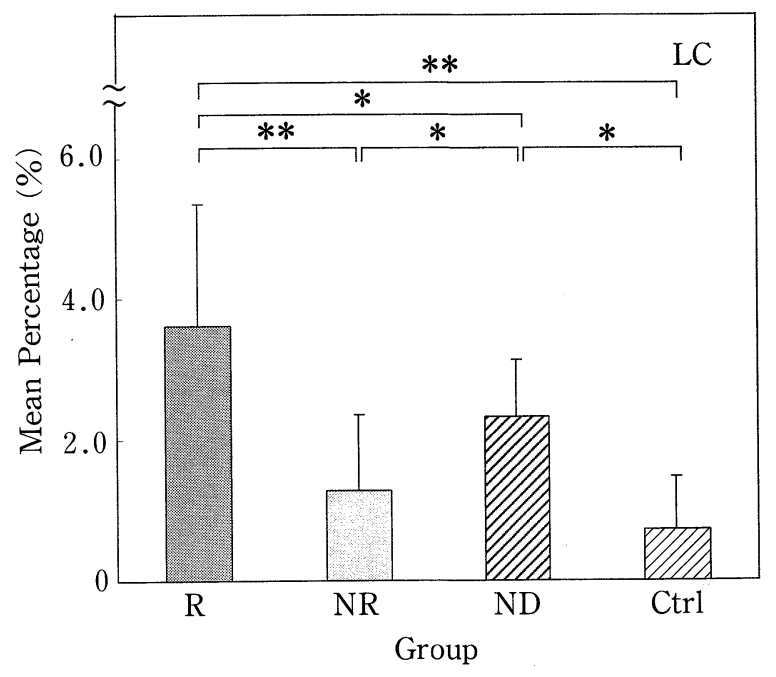

* Statistically significant at $\mathrm{p}<0.05$

** Statistically significant at $\mathrm{p}<0.01$ (Mann-Whitney's U test)

図 8 単位面積当たりの全上皮細胞に占める LC の存在比率（平均土標準偏差\%)

$\mathrm{LC}$ の存在比率は, $\mathrm{R}$ 群 $>\mathrm{ND}$ 群 $>\mathrm{NR}$ 群 $>$ Ctrl 群の順に高く, R 群と ND群, R 群と $\mathrm{NR}$ 群, ND群と NR 群, R 群と Ctrl 群, お よびND群とCtrl 群との間にそれぞれ $\mathrm{p}<$ $0.05, \mathrm{p}<0.01, \mathrm{p}<0.05, \mathrm{p}<0.01$ および $\mathrm{p}<$ 0.05 で有意差を認めた。なお，NR群と Ctrl 群との間には有意差は認められなかった。

に関するさらなる研究を行う予定である。

さらに, NF 増殖症罹患歯肉における炎症性細胞の 動態についての詳細な研究は少なく, わずかにNery $ら^{28)}$ が形質細胞の増加を, また, Kunimatsu ら クロファージの活性化について報告している程度であ る。一方, フェニトイン誘導性歯肉増殖症においても 免疫反応の活性化傾向が認められ, 形質細胞 ${ }^{16,29,30)}$, $\mathrm{LC}^{16 \sim 18)}$ および上皮直下の $\mathrm{T}$ 細胞の増加 ${ }^{18,31)}$, さらに マクロファージの活性化 ${ }^{32)}$ 等が報告されている。そこ で, LCと CD 3 陽性細胞の集積分布について詳しく 調べたところ, R 群と ND群の両方の歯肉において 両者に明らかな関連性が認められた。さらに，LCの 抗原呈示をする細胞がT細胞であり, ND 群に比べ R 群においてより多くの LCが認められたことから, $\mathrm{NF}$ 歯肉増殖症の歯肉組織ではTリンパ球の仲介する 免疫反応の活性化が生じている可能性が示唆された。

今回，我々が観察した NF およびフェニトイン誘 導性の増殖性歯肉は, Seymour $ら^{33)}$ や Saito $5^{34)}$ の 報告と同様, 類似した炎症像を呈したが, 炎症の程度 による差異を詳しく調べるため, 炎症性細胞の浸潤程

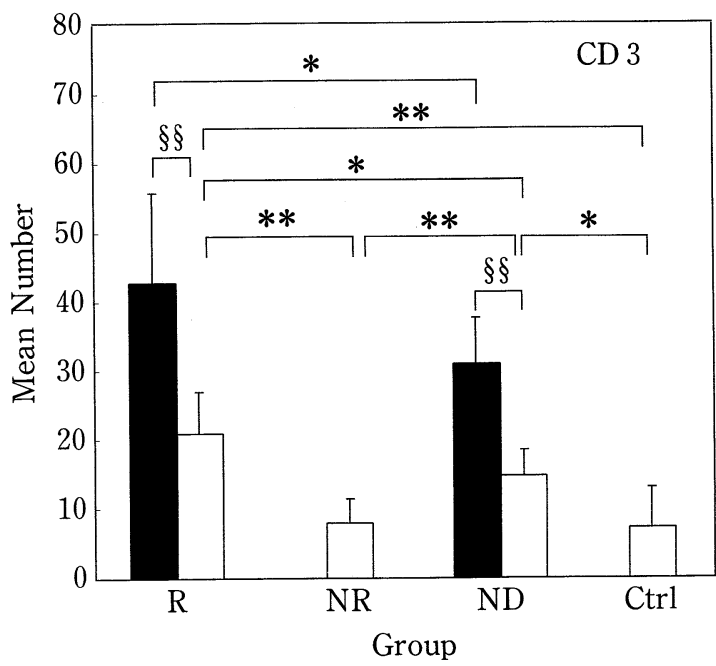

- LC-rich region $\square$ LC-poor region

* Statistically significant at $\mathrm{p}<0.05$

** Statistically significant at $\mathrm{p}<0.01$ (Mann-Whitney's U test)

$\S \S$ Statistically significant at $\mathrm{p}<0.01$ (Wilcoxon signed-ranks test)

図 9 歯肉上皮を LCに富んだ領域（LC-rich region)と少ない領域 (LC-poor region）に分けた場合の歯肉上皮直下結 合組織中 CD 3 陽性細胞数（平均土標準 偏差)

$\mathrm{R}$ 群と ND群の rich および poor 領域間 $(\mathrm{p}<0.01)$ において，また両群の LC-rich 領 域間（ $\mathrm{p}<0.05 ） て ゙$ 有意差が認められた。

度による比較検討を試みた。しかし， R 群における上 皮内の LC の比率は, 強い炎症性細胞浸潤領域と弱い 領域との間で有意差が認められず，NF 歯肉増殖症に おける LC の発現率と炎症性紲胞浸潤との関遇を明ら かにすることはできなかった。この結果は，歯周疾患 においても両者が関連するか否かについての統一見解

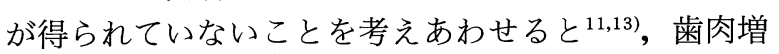
殖症を含めた歯周疾患における口腔上皮の免疫反応の 複雑さを反映しているのかもしれない(13)。これに反し て，上述したように LC 数と CD 3 陽性細胞数の間に は緊密な相関関係が認められたことから，本疾患では 抗原提示機能を持つ LCが増加したものと推察され る。

これまでLCの検出マーカーとしては, CD $1 \mathrm{a}$, HLA-DR S-100 蛋白などが知られている。 S-100 蛋白は細胞内のリン酸化反応やカルシウムイオン調節 および細胞骨格形成に関与し, LCでは細胞質にび漫 性に分布する ${ }^{35)}$ 。また, 従来より細胞増殖あるいは細 


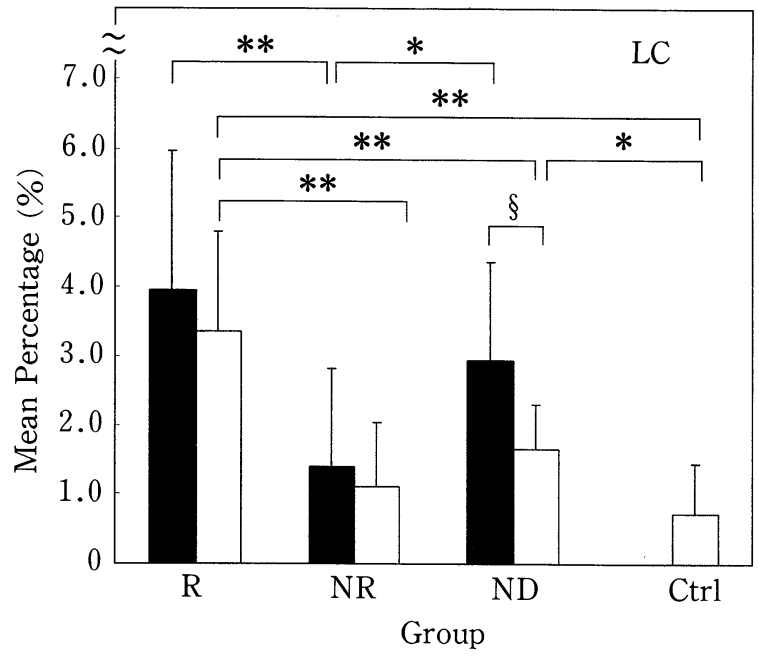

- Severe infiltration $\quad \square$ Mild infiltration

* Statistically significant at $\mathrm{p}<0.05$

** Statistically significant at $\mathrm{p}<0.01$ (Mann-Whitney's U test)

$\S$ Statistically significant at $\mathrm{p}<0.05$ (Wilcoxon signed-ranks test)

図 10 結合組織内の炎症性細胞浸潤密度の高 い領域（Severe infiltration 部）およ び低い領域 (Mild infiltration 部) で の LCの存在比率 (平均土標準偏 差\%)

ND群でのみ Severeおよび Mild infiltration 部間で有意差を認めた $(\mathrm{p}<0.05)$ 。また， 炎症性細胞浸潤密度の低い領域における $\mathrm{R}$ 群 の上皮内 LC の比率は，他群に比べて有意に高 い値を示した。

胞周期に関連したマーカーとしても用いられ ${ }^{10,36)}$, Adenoma などの唾液腺腫湯 ${ }^{37)}$ や Histocytosis- $\mathrm{X}^{38)}$ どの増殖性疾患における重要な診断マーカーとしても 使用されている。一般に，抗 S-100 蛋白抗体を使用 したパラフィン切片による LC の検出率は, 抗 CD 1 a 抗体や抗 HLA-DR 抗体を用いた凍結切片によるも のより低いと考えられている10)。しかし，我々は従来 より本実験と併行して増殖症歯肉組織における居住細 胞の質的・量的変化ならびに局所に特異的に出現する 細胞の同定をパラフィン切片上での抗原抗体反応を通 して検索しているため ${ }^{7,8,18)}$, 本研究においてもパラ フィン切片で使用可能な抗 S-100 蛋白抗体を使用し た。ただ，ここで考慮しておかなければならないこと は，本抗体は LC の分布領域に近いメラニン生成細胞 をも認識してしまうため ${ }^{10)}$, 計測值に両者が混在して いる可能性が考えられることである。さらに，LCと
メラニン生成細胞は類似の樹枝状形態を呈するた め $^{26)}$, 基底層の陽性細胞を形態の上から光学顕微鏡的 に鑑別することも困難である。そこで，両者を区別す るために，シュモール染色によりメラニン産生細胞を 同定し ${ }^{21)}$ ，同一領域に打ける計測值を全 S-100 蛋白 陽性細胞から控除することにより，LC 数を求める方 法を採用した。しかし，LCとメラニン生成細胞のよ り正確な鑑別には，パラフィン切片だけでなく凍結切 片を用いた方法も検討する必要があると思われる。こ の点については今後の研究の課題としたい。

以上の結果より, NF 歯肉増殖症罹患歯肉において は, プラークにより引き起こされる歯肉炎や NF 非 感受性歯肉と比較して, LC を始めとする宿主防御機 構に特異性が認められることが示唆された。しかしな がら, より詳細な解明には LC の検出法の工夫や炎症 性細胞の産生するサイトカインやプロテアーゼなどの 炎症性メディエーターにも焦点を当てた検索が必要で あると考えられた。このことは，NF 歯肉増殖症の発 症, ならびに進展のメカニズムの追求や治療法につい ての有益な知見を加えうることが推察された。

本研究は, 平成 7 年度文部省科学研究奨励研究 $\mathrm{A}$ （課題 番号 07771769）の補助を受けて行われたことを付記する。

\section{文献}

1) Ramon, Y., Behar, S., Kishon, Y. and Engelberg, I. S. : Gingival hyperplasia caused by nifedipine-a preliminary report. Int. J. Cardiol., $5: 195-206$, 1984.

2) Rateitschak-Plüss, E.M., Hefti, A., Lörtscher, R. and Thiel, G. : Initial observation that cyclosporin-A induces gingival enlargement in man. J. Clin. Periodontol., 10 : 237-246, 1983.

3) Kimball, O.P.: The treatment of epilepsy with sodium diphenyl-hydantoinate. J. Am. Med. Ass., 112 : 1244-1245, 1939.

4) Hassell, T.M. and Hefti, A.F. : Drug-induced gingival overgrowth: Old problem, new problem. Crit. Rev. Oral Biol. Med., 2 : 103-137, 1991.

5) Seymour, R.A., Thomason, J.M. and Ellis, J.S. : The pathogenesis of drug-induced gingival overgrowth. J. Clin. Periodontol., 23 : 165-175, 1996.

6) Nishikawa, S., Nagata, T., Morisaki, I., Oka, T. and Ishida, H. : Pathogenesis of drug-induced gingival overgrowth. A review of studies in the rat model. J. Periodontol., 67 : 463-471, 1996.

7) Kunimatsu, K., Ozaki, Y., Aoki, Y. and Kato, I. : Possible roles of medullasin in nifedipine-induced 
human gingival overgrowth. Archs. oral Biol., 41:111-115, 1996.

8）尾崎幸生，國松和司，田尻公一，原 宜興，加藤伊 八：ヒトニフェジピン歯肉増殖症における抗 PCNA 抗体を用いた線維芽細胞の増殖に関する研 究. 日歯周誌, $39 ： 217-225,1997$.

9) Lombardi, T., Hauser, C. and Budtz-Jorgensen, E. : Langerhans cells: structure, function and role in oral pathological conditions. J. Oral Pathol. Med., 22: 193-202, 1993.

10) Barrett, A.W. and Scully, C. : S 100 protein in oral biology and pathology. J. Oral Pathol. Med., 23 : 433-440, 1994.

11）宮武祥子，原 宜興，前田勝正，赤峰昭文，相田宜 利，青野正男：歯周疾患における免疫系細胞の動態 に関する免疫組織学的研究. 2. ランゲルハンス細 胞の動態. 日歯周誌, $28 ： 179-185,1986$.

12) Johannessen, A.C., Nilsen, R., Knudsen, G.E. and Kristoffersen, $\mathrm{T}$. : In situ characterization of mononuclear cells in human chronic marginal periodontitis using monoclonal antibodies. J. Periodont. Res., 21:113-127, 1986.

13) Baelum, V., Fejerskov, O. and Dabelsteen, E. : Langerhans cells in oral epithelium of chronically inflamed human gingivae. J. Periodont. Res., 24 : 127-136, 1989.

14) Barak, S., Engelberg, I.S. and Hiss, J. : Gingival hyperplasia caused by nifedipine. Histopathologic findings. J. Periodontol., 58 : 639-642, 1987.

15) Niimi, A., Tohnai, I., Kaneda, T., Takeuchi M. and Nagura, H. : Immunohistochemical analysis of effect of cyclosporin A on gingival epithelium. J. Oral Pathol. Med., 19:397-403, 1990.

16) Ibáñez, P., Sagredo, E. and Pino, A. : Changes in the number and distribution of Langerhans cells in the hydantoin hyperplastic gingiva as compared with the clinically normal one. Histology and Histopathology, 5:433-438, 1990.

17) Kinane, D.F., Drummond, J.R. and Chisholm, D. M. : Langerhans cells in human chronic gingivitis and phenytoin-induced gingival hyperplasia. Archs. Oral Biol., 35 : 561-564, 1990.

18）田尻公一，國松和司，尾崎幸生，原 宜興，加藤伊 八：フェニトイン歯肉増殖症に打ける抗 S-100 蛋 白抗体陽性ランゲルハンス細胞の上皮内分布および 密度に関する免疫組織学的研究. 日歯周誌, 38 ： 168-175, 1996.

19) Cocchia, D., Michetti, F. and Donato, R. : Immunochemical and immuno-cytochemical localization of S-100 antigen in normal human skin. Nature, 294:85-87, 1981.

20) Löe, H. : The gingival index, the plaque index and the retention index systems. J. Periodontol., $38: 610-616,1967$.

21) Gupta, S.K., Rajwanshi, A.K. and Das, D.K. : Fine needle aspiration cytology smear patterns of malignant melanoma. Acta. Cytologica., 29:983988, 1985 .

22) Newcomb, G.M., Seymour, G.J. and Powell, R. N.: Association between plaque accumulation and Langerhans cell numbers in the oral epithelium of attached gingiva. J. Clin. Periodontol., $9: 297-304,1982$.

23) Cruchley, A.T., Williams, D.M., Farthing, P.M., Speight, P.M., Lesch, C.A. and Squier, C.A. : Langerhans cell density in normal human oral mucosa and skin : relationship to age, smoking and alcohol consumption. J. Oral Pathol. Med., $23: 55-59$, 1994.

24) van Loon, L.A., van Elsas, P.W., Bos, J.D., ten Harkel-Hagenaar, H.C., Krieg, S.R. and Davidson, C.L.: T-lymphocyte and Langerhans cell distribution in normal and allergically induced oral mucosa in contact with nickel-containing dental alloys. J. Oral Pathol. Med., 17 : 129-137, 1988.

25) Henderson, J.S., Flynn, J.C., Tucci, M.A., Tsao, A K., Zebrowski E.J., Odlum, O. and Johnson, R.B. : Site-specific variations in metabolism by human fibroblasts exposed to nifedipine in vitro. J. Oral Pathol. Med., 26 : 6-10, 1997.

26）二階宏昌，伊集院直邦：口腔上皮内の樹枝状澄明細 胞に関する考察. 広島大学歯学雑誌, $7: 102-126$, 1975.

27) Relay, P.A. : Function of high-level melanocyte. Nature, $201: 1031,1986$.

28) Nery, E.B., Edson, R.G., Lee, K.K., Pruthi, V.K. and Watson, J. : Prevalence of NifedipineInduced Gingival Hyperplasia. J. Periodontol., 66:572-578, 1995.

29) Butler, R.T., Kalkwarf, K.L. and Kaldahl, W.B. : Drug-induced gingival hyperplasia : phenytoin, cyclosporin, and nifedipine. JADA, $114: 56-60$, 1987.

30) Dill, R.E. and Iacopino, A.M. : Myofibroblasts in phenytoin-induced hyperplastic connective tissue in the rat and in human gingival overgrowth. J. Periodontol., 68:375-380, 1997.

31) Dahllöf, G., Modéer, T., Otteskog, P. and Sundqvist, K-G. : Subpopulation of lymphocyte in connective tissue from phenytoin-induced gingival overgrowth. Scand. J. Dent. Res., $93: 507-512$, 1985.

32) Iacopino, A.M., Doxey, D., Cutler, C.W., Nares, S., 
Stoever, J.F., Gonzales, A. and Dill, E. : Phenytoin and cyclosporin A specifically regulate macrophage phenotype and expression of plateletderived growth factor and interleukin-1 in vitro and in vivo: Possible molecular mechanism of drug-induced gingival hyperplasia. J. Periodontol., 68: 73-83, 1997.

33) Seymour, R.A. and Heasman, P.A. : Drug and the periodontium. J. Clin. Periodontol., $15: 1-16$, 1988.

34) Saito, K., Mori, S., Iwakura, M. and Sakamoto, S. : Immunohistochemical localization of transforming growth factor $\beta$, basic fibroblast growth factor and heparan sulphate glycosaminoglycan in gingival hyperplasia induced by nifedipine and phenytoin. J. Periodont. Res., 31 : 545-555, 1996.
35) Donato, R. : Perspectives in S-100 protein biol ogy. Review Article. Cell Calcium, $12: 713-726$, 1991.

36) Kligman, D. and Hilt, D.C. : The S 100 protein family. Trends. Biochem. Sci., $13:$ 437-443, 1988.

37) Hara, K., Ito, M., Takeuchi, J., Iijima, S., Endo, T. and Hidaka, H. : Distribution of S-100 b protein in normal salivary glands and salivary gland tumors. Virchows Archiv. -A, Pathol. Anat. \& Histopatho., 401:237-249, 1983.

38) Stewart, J.C., Regezi, J.A., Lloyd, R.V. and McClatchey, K.D. : Immunohistochemical study of idiopathic histiocytosis of the mandible and maxilla. Oral Surg. Oral Med. Oral Pathol., 61 : 48-53, 1986.

連絡先：

長崎大学歯学部歯科保存学第二講座

干 852-8588 長崎市坂本 1-7-1 